\title{
Can Job Evaluation Improve Women's Wages?*
}

$$
\text { by }
$$

\section{Åsa Löfström}

\author{
Department of Economics \\ Umeå University \\ S- 90187 Umeå
}

Sweden

June 1996 


\section{Introduction}

Women's wages and wage-discrimination have received a great deal of attention in recent decades. The main reason for this is, of course, the findings exposed in various studies. Wage discrimination of women as well as low pay in female-dominated jobs are well-documented today. 1 These results have contributed to a growing interest for questions such as 'what constitutes wages for different jobs', 'are existing wages fair' and 'can injustices in the wage determination process be corrected'. The ILO convention No 100 about 'Equal pay for equal work' has been in practice in some countries since the beginning of the 1950s, but for most industrialized countries the ratification took place much later. ${ }^{2}$ The ILO convention has obviously been no guarentee for assuring equal pay for those men and women performing equal work.

The increase in the female participation rate during the 1960s, 1970s and 1980s made the sex segregation in the labour market yet more obvious. ${ }^{3}$ It is often argued that both sex-segregation and productivity differentials are important explanations for the existing wage differentials between men's and women's jobs. The interest in comparable worth policies has increased because of the difficulty to measure productivity in many female dominated jobs but also because of the devaluation of jobs the greater the proportion of women employed in them. The demands for equal pay today do not, therefore, just comprise those men and women performing 'equal work' but also those performing 'work of equal value'. By comparable worth policy we mean a policy which is based on the doctrine that an employer should pay employees in jobs dominated by women the same as employees in jobs dominated by men if the jobs require comparable skills, effort, responsiblitity and working conditions. 4,5

The distinction between the conventional 'equal pay for equal work' and 'equal pay for work of equal value' is that the former requires equal pay for jobs that are substantially

\footnotetext{
1 See e g Sorensen (1990, 1994), Polacheck \& Siebert (1993), Palme \& Wright (1992), Barth, (1993), Blau \& Ferber (1992), Gunderson (1989), Löfström (1989).

2 Sweden ratified this convention in 1962.

3 In these three decades almost one million women entered the Swedish labour market. The participation rate (women 16-64 years) rose from about $50 \%$ in 1960 to just above 80 per cent in 1990 . In 1990 almost half of the labour force was female.
}

4 Comparable worth has been more or less in progress since the 1970s in US, Canada, UK and Australia. In Sweden and other Nordic countries the interest for comparable worth became evident at the end of the 1980s. The main reasons for this lrate interest were primarly two: gradually increasing relative wages for women since the 1960 s and a high degree of union membership among women. Due to changes taking place from the middle of the 80 s the trend with increasing relative wages was broken and the interest for comparable worth became evident.

5 Comparable worth has been analysed and discussed in e g Sorensen $(1990,1994)$, Gunderson (1994), Perlman \& Pike (1994), Löfström (1992), Weiner \& Gunderson ( 1990), Evans \& Nelson (1989), Acker (1989) and Aaron \& Lougy (1986), Audie-Figeroa (1983). 
similar. The similarity is determined in terms of skill, effort, responsibility, and working conditions. However, these same four criteria are also used in identifying jobs that are of equal value. The difference is in the relationships between the four criteria. Jobs are substantially similar, if each of the critera is substantially similar in the female and male job. 'Equal value' on the other hand is based on the sum or composite of skill, effort, responsibility and working conditions in each different occupation. Rather than each of the critera being similar, the total value of the four must be similar for the jobs to be of equal value.

The method for comparable worth policy is systematic job evaluation, where the contents of the job and not the charateristics of the employees performing the job are the object. The first stage in a job evaluation process is to obtain a non-biased determination of the "value" (or the difficulty) of different jobs within an organisation. The next step is to adjust the existing wage structure in accordance with the evaluation. Since many jobs are assumed to be exposed to subjective discriminatory assessments, systematic job-evaluation is seen as means of eliminating bias in wage determination. The method is of particular interest for women since women's jobs, irrespective of level, are often lower paid than comparable male jobs. A systematic evaluation procedure makes the criteria used and the steps in the evaluation process explicit. The basic idea is that increased knowledge of both the contents and the demands of different jobs ought to give a better assessment of both women's and men's productivity. ${ }^{6}$

The aim of this study is to test empirically whether job-evaluation within an organisation, if implemented, would have any effect on the existing wage-structure, especially on the relative wages of men and women. The methodology is simple. First, we present the results from two job-evaluations accomplished for part of the Swedish university sector. These results are used to estimate wage-functions (i.e. functional relations between the quantity of evaluation points and existing wages) and finally, this is used to compare hypothetical "job-evaluation wages" with existing wages.

\section{The theory of job-evaluation}

The economic theory of wage-determination is expressed in terms of the demand and supply of labour in an idealised perfect market with perfect competition. Of course real world imperfections, such as unemployment, discrimination or lack of information make this theory an approximation of actual conditions. Opponents of job-evaluation argue that the introduction of this system in the wage-determining process implies the addition of yet another market distortion. Nevertheless job-evaluation can also rectify the lack of knowledge, increase information on true productivities and, in this way, improve the 
functioning of the market. A simple way to illustrate this is shown in the figure presented below.

Figure 1: Job-evaluation and changes in labour supply and wages.

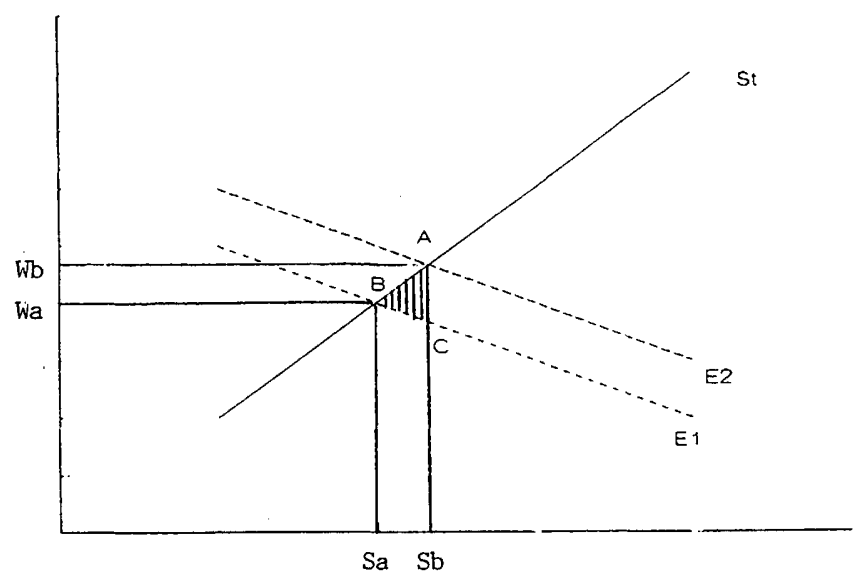

Assume that the supply of labour is $S_{t}$ and that we believe $E_{1}$ to be the true productivity curve. Accordingly, the wage will be $\mathrm{W}_{\mathrm{a}}$ and the number of employees $\mathrm{S}_{\mathrm{a}}$. Assume now that a job-evaluation study reveals that the non-biased and true productivity curve is $\mathrm{E}_{2}$. Accordingly, the wage moves to the equilibrium level $\mathrm{W}_{\mathrm{b}}$ and the number of employees increases to $S_{\mathrm{b}}$. This can imply that information on individuals' productivity can also be missing. The total economic gain (for society as a whole) of finding the 'true' marginal productivity curve will then be given by the area $\mathrm{ABC}$ in the figure.

This situation can be extended to the case when the productivity information is sexbiased, i.e. when the overall average wage level is correct, but when productivity is assumed to be lower (than it actually is) for women and higher for men. Figure 2 depicts this situation. 
Figure 2: Job-evaluation and changes in labour supply and wages.

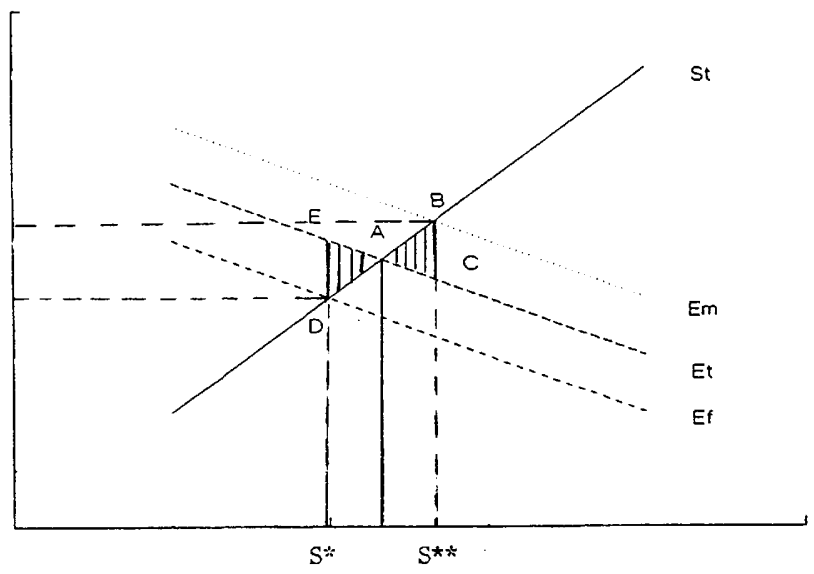

Assume that $S_{t}$ is the supply curve (equal for both men and women) and $E_{t}$ the true productivity curve for both sexes. Due to discrimination, lack of information etc the productivity curve for men is assumed to be equal to $E_{m}$ in the figure which means a higher productivity than the true. For women the productivity curve is believed to be equal $\mathrm{E}_{\mathrm{f}}$. If systematic job-evaluation moves the market's demand curves from the "assumed" to the "true", then wages and employment will increase for women, decrease for men and society will gain $\mathrm{ABC}+\mathrm{ADE}$ in economic efficiency.

\section{Data}

The data for this study are taken from two job-evaluations performed at three Swedish universities (colleges). The evaluations involved cooperation between representatives for the employer and the employees. The occupations evaluated were a selected group of jobs dominated by either men or women or were mixed (i.e. with no sex dominating the number of employees). ${ }^{7}$

The two job evaluation systems used were the American HAY-system and the Swedish BVT-system. ${ }^{8}$ In essence they are the same (i.e. methods of allocating points to different jobs according to a specific scale and specific criteria). However one explicit aim of the

7 Job evaluation is usually done within one and the same organisation (firm or company) The universities in this study are obviously three separate establishments but since the employer is the same (the state) they are treated as one single organisation. The project is depicted in the report: Arbetsvärdering-en metod att utjämna löneskillnader mellan kvinnor och män? Umeå University.

8 HAY: The hay-system was created in the US. According to them it is the most well known system in the world. More than four million different occupations/positions have been evaluated using this. 
HAY-system is to correct for injustices between men's and women's jobs, this is not the case with the BVT-system. Both systems are supposed to be sex-neutral, which means, for example, that the special kinds of characteristics of both men's and women's jobs are recognised and valued. ${ }^{9}$ The persons doing the evaluation are also supposed to ignore whether it is a man or a women performing the actual job, whether the job is performed well or not etc, since the evaluation is about the job and not about the person performing it. ${ }^{10}$ This also implies that the market solution, i.e. the actual wage rate, should be ignored.

The HAY-system is based on three main criteria; knowledge, problem-solving and accountability. ${ }^{11}$ The evaluation according to the BVT-system is based on eight criteria; education, experience, problem solving, supervision of others, coordination and cooperation, accountability, effort and working conditions. The points scored on the different criteria are, in both cases, added together to give a total score. ${ }^{12}$

BVT: Befattningsvärdering Tjänstemän (BVT) is a system for ranking the employees' tasks according to degree of difficulty. The system has been developed by the Confederation of Swedish Employers (SAF).

9 A sex neutral evaluation may demand a new or broader definition of those factors already in the system. A few examples can illustrate this. Traditionally a 'heavy job' is connected with heavy weights but today a heavy job may also be a job with lots of light lifting. 'Dirty jobs' are not only those jobs where you get dirty but also jobs where the task is to clean up, take away blood, pus, vomit and other human waste for example. The definitions of a 'responsible job' must also include responsibility for human beings their life, upbringing, health and security as well as economic responsibility for expensive equipment.

10 Confusing jobs with individual employees is a common problem in evaluating jobs even when gender bias is not a concern. It is not unusal to hear: This is Charlie's job. Charlie has not been working very hard lately. I do not think the job should be evaluated any higher. This evaluator is confusing the tasks and the duties of the job - the concern of job evaluation - with the performance of the job incumbent - the concern of performance appraisal. (Weiner \& Gunderson p.49)

11 These main factors are split up into different specific criteria such as skill, social competence, creativity etc. One must know the particular aspect or definition of the factor which is being used. Some factors and some particular definitions favour duties traditionally associated with men's while some favour women's jobs (see also footnote 9).

12 All the critera are important or they would not be utilized. However, they may not be of equal importance and that is why the evaluaters may make a weighting. In this particular case, as far as I know, no explicit weighting has been done but, due to the way the evaluations are made, we can suppose that indirect weightings have been made. 


\section{Empirical results}

Eleven different occupations or offices were valued with HAY and forty with the BVT system. The dispersion in educational background for the population was very small in the HAY-study and quite large in the BVT-study. ${ }^{13}$ The differences between men and women regarding age and experience were also less in the HAY study.

About 250 persons' positions were used in the HAY evaluation and 600 in the BVT. Since every single person's job was valued, the dispersion in points could become great between individual jobs within the same occupational group. Table 1 below gives examples of the size of the dispersion in some of the occupations included in this study.

Table 1: Dispersion in points in some of the occupations evaluated according to either the HAY- system or the BVT-system.

\begin{tabular}{llll|}
\hline & BVT & & HAY \\
\hline Assistant & $21-41$ & Librarian & $270-383$ \\
Assistant director & $50-64$ & Assistant lecturer & $323-568$ \\
Research engineer & $28-69$ & Secretary & $268-282$ \\
Laboratory assistant & $29-36$ & Intendant & $228-393$ \\
Technician & $20-39$ & Assistant director & $317-619$ \\
\hline
\end{tabular}

The dispersion in points shows clearly the difficulties involved in determining a specific and absolute number of points for a particular occupation. In the empirical analysis below, we are using both individual values and mean values for respective occupation.

The means for different occupations are shown in Tables $2 \mathrm{a}$ and $2 \mathrm{~b}$. The evaluation points (HAY and BVT), the actual mean wages for the occupation and lastly the proportion of women in the different occupations are given.

13 This indicates that the group of occupations evaluated in the HAY-study was more homogenous than the occupations evaluated using the BVT-system. 
Table 2a: Mean points, mean salary (SEK/month) and proportion of women within different occupations evaluated according to the BVT-evaluation.

\begin{tabular}{|c|c|c|c|}
\hline Occupation & Point & Salary & \% women \\
\hline Cleaner & 15 & 11553 & $96 \%$ \\
\hline Office caretaker/supplies & 15 & 12059 & $25 \%$ \\
\hline Kitchen assistant & 16 & 12421 & $100 \%$ \\
\hline Ass.1st cleaner & 20 & 11925 & $100 \%$ \\
\hline Caretaker & 20 & 12323 & $17 \%$ \\
\hline Office manager & 23 & 13544 & $0 \%$ \\
\hline Ass.librarian & 27 & 13097 & $65 \%$ \\
\hline Animal keeper & 28 & 13054 & $43 \%$ \\
\hline 1st cleaner & 28 & 12833 & $92 \%$ \\
\hline 1st instrumentmaker & 28 & 14580 & $8 \%$ \\
\hline Technician & 29 & 13348 & $10 \%$ \\
\hline Assistant & 30 & 13679 & $100 \%$ \\
\hline Printer & 30 & 12455 & $33 \%$ \\
\hline Engineer & 32 & 14391 & $16 \%$ \\
\hline Senior assistant & 33 & 13304 & $100 \%$ \\
\hline Laboratory assistent & 33 & 13625 & $87 \%$ \\
\hline 1st secratary & 38 & 15788 & $80 \%$ \\
\hline Reserach engineer & 42 & 15237 & $14 \%$ \\
\hline Librarian & 43 & 15917 & $86 \%$ \\
\hline Assistant director & 53 & 17270 & $43 \%$ \\
\hline Intendant & 53 & 16505 & $75 \%$ \\
\hline Deputy head of division & 57 & 20987 & $0 \%$ \\
\hline Principal research engineer & 60 & 18505 & $0 \%$ \\
\hline Principal librarian & 68 & 18708 & $76 \%$ \\
\hline
\end{tabular}


Table 2b: Mean points, mean salary (SEK/month) and proportion of women within different occupations evaluated according to the HAY-evaluation.

\begin{tabular}{|llll|}
\hline Occupation & Point & Salary & \% women \\
\hline Research engineer & & & \\
Secratary & 265 & 14506 & $18 \%$ \\
Librarian & 269 & 14874 & $100 \%$ \\
First secratary & 314 & 15509 & $83 \%$ \\
Intendant & 344 & 16196 & $82 \%$ \\
Assistant director & 351 & 16615 & $75 \%$ \\
Principal research engineer & 371 & 18650 & $50 \%$ \\
Asststant lecturer & 440 & 18447 & $0 \%$ \\
Deputy head of division & 441 & 19646 & $30 \%$ \\
Principal librarian & 486 & 22257 & $14 \%$ \\
Senior lecturer & 488 & 19481 & $75 \%$ \\
\hline
\end{tabular}

A visual inspection of Tables $2 \mathrm{a}$ and $2 \mathrm{~b}$ reveals that, in general, mean wages rise with the number of (mean) HAY- or BVT points. However, the correlation is far from perfect. Some occupations may have about the same mean points but different (mean) wage or vice verse. The correlation is about the same for mean and individual valuations. Simple correlation between actual wages and HAY-points (on the individual level) is 0.82 and between wages and BVT-point 0.83 . The correlation was slightly higher for women than for men.

The table also reveals that, in general, there is a good correlation between HAY- and BVT-points. For those eight occupations that were the same in both evaluations, the simple correlation was 0.8667 .

Pay and points, individual estimates.

It is possible to make (at least) three assumptions in order to establish the relationship between wages and evaluation points. We can assume that men's wages give the unbiased expression for true productivity or that women's wages give the unbiased expression or we can assume that the best expression is given by an average of men's and women's wages. We do not a priori know which one of these (if any) is true. However for the purposes of this paper this does not present a problem. If any sex is under- (or over-)paid, it does not matter whether we express this as if, for example, men obtain correct wages and women much too low (or too high) or if men obtain somewhat unfairly high wages and women somewhat unfairly low. What is of interest for us is the relationship between men's and women's wages and normally it should not matter which relationship between pay and points is used as the norm. 
For this study we have chosen to use the average relationship between wages and evaluation points as the norm. The following log-linear relationship is used:

$$
\ln (w)=a_{o}+a_{1}^{* P}+e
$$

where $w$ is wage rate, $a_{\mathrm{O}}$ and $a_{1}$ parameters, $P$ point estimate (HAY or BVT points) and $e$ is the error term. The parameters are estimated from individual data. The results are shown in the table below:

Table 3: Results from linear regressions $\ln (w)=a_{0}+a_{1} * P+e$ (t-values in brackets).

\begin{tabular}{lllll|}
\hline Study & $\hat{\mathrm{a}}_{\mathrm{O}}$ & $\hat{\mathrm{a}}_{1}$ & $\mathrm{R}^{2}$ (Adj) & $\mathrm{N}$ \\
\hline$H A Y$ & 9.378 & .0010 & 0.67 & 257 \\
& $(433.61)$ & $(22.62)$ & & \\
$B V T$ & 9.2448 & .0088 & 0.70 & 597 \\
& $(1111.06)$ & $(36.69)$ & & \\
\hline
\end{tabular}

Correlation coefficients and t-values are very high in both regressions. ${ }^{14} \mathrm{~A}$ visual inspection of actual wage rate vs the estimated equation reveals no systematic error structure.

If individual wages are calculated on the basis of the estimated relations in Table 3 , it is possible to compare these predicted wages with the actual. Should the payment be in accordance with the evaluation and the estimated relationship, changes in the total wage-sum for men and women separately would be as shown in Table 4.15

14 The multiple correlation level $\left(\mathrm{R}^{2}\right)$ for "normal" wage-equations with individual data on e.g. occupation, age, experience, education etc does not normally exceed 0.6 .

15 The estimations are made for those individuals actually in the selected groups. Accordingly, no estimations are made for the whole group of employees in the organisation. 
Table 4: Changes in the wage sums for jobs evaluated by HAY and BVT.

\begin{tabular}{|lll|}
\hline & HAY & BVT \\
\hline Men & $-2.7 \%$ & $-1.6 \%$ \\
Women & $+3.0 \%$ & $+0.3 \%$ \\
\hline
\end{tabular}

According to the HAY-estimate, the total wage-sum for women should increase by about 3.4 per cent while the sum for men should decrease by 2.3 per cent. In the BVTestimation, the increase should be about 0.6 per cent for women whereas for men there should be a reduction of 1.3 per cent. ${ }^{16}$ Accordingly, the HAY-evaluation showed that women's wages should increase by about 6 per cent in relation to men's, whereas the BVT-study indicated that the increase should be about 2 per cent. ${ }^{17}$

The change in wages was, as expected, not equal for men and women but they were not uniform within gender groups either. Among women as well as among men, there were winners and losers. In the table below, we have indicated the proportion of each group that should have unchanged salaries (i.e. change less than $+/-500 \mathrm{SEK} /$ month), increased $(>500 \mathrm{SEK})$ or decreased $(<500 \mathrm{SEK})$ salaries according to the HAYevaluation.

Table 5: Differences in predicted and actual salaries according to the HAY-evaluation. Proportion men and women in different groups: A: Differences are less than +/-500 SEK, B: actual wages < predicted or C: actual wages $>$ predicted.

\begin{tabular}{|lll|}
\hline Category & Men & Women \\
\hline A: $+1-0$ & $19 \%$ & $23 \%$ \\
B: actual wages < pred. & $30 \%$ & $49 \%$ \\
C: actual wages $>$ pred. & $51 \%$ & $28 \%$ \\
\hline $\mathrm{N}=$ & 145 & 112 \\
\hline
\end{tabular}

16 Theoretically the change in the total wage sum ought to be zero. Probably due to some misspecification of the model there was a minor deviation. To get a correct estimation of the changes we, therefore, should add 0.4 (hay) respective 0.3 per cent (bvt) to the respective wage sums for men and women.

17 These estimations are based upon a strict implementaion of the results. This means that increases as well as decreases in salaries are taken for granted. Experience shows, however, that decreases are very seldom implemented and the actual size of the increases are hardly realized either, at least not at once. 
In both groups, about 20 per cent would have an unchanged salary. However, 50 per cent men would experience a decline in wages and only 30 per cent an increase, wheras the figures are the reverse for women: 50 per cent winners and 30 per cent losers. Netting out winners and losers in each group, we can say that the net effect of the HAYevaluation is to 'create' 20 per cent winners among the women's group and 20 per cent losers among the men's group.

Finally, we have also checked for statistical significance between male- and female wages by adding a sex-dummy (women =1) to equation (1). For both the HAY- and the BVT-estimates, this dummy was significant at the $99 \%$ confidence level, the t-value being (-) 5.15 for HAY and (-) 2.72 for BVT. The size of the dummy estimate was around -.02 for BVT and -.06 for HAY. This indicates that for a job with the same evaluation point, a woman obtained 2 per cent less salary than a man according to the BVT evaluation and 6 per cent less according to the HAY evaluation.

\section{Job evaluations and sex-dominated occupations}

One theory of wage discrimination states that the reason for women's low wages is a crowding effect, wheras another theory points to statistical discrimination. In short, these theories claim that jobs that are predominantly occupied by women are "degraded" in the sense that the true productivity is believed to be lower, the higher the share of women in the labour force. Accordingly, wage-discrimination against women occurs for two reasons: firstly a woman gets lower pay for any job; and secondly, should the job be a typical women's job, another negative element is added.

This hypothesis was tested with the underlying assumption that the HAY and BVT points respectively were a true index of productivity. In these tests, we also accounted for the seniority effect, i.e. the fact that most employees recieve higher wages with age, irrespective of whether the job performance improved or not. The regression equation was accordingly:

$$
\ln (w)=a+b^{*} P+c^{*} D+d^{*} \text { Age }+e^{*} \text { Age }{ }^{2}+f^{*} \text { Share }+e
$$

where $w$ is the wage rate, $P$ is the point estimate (HAY or BVT points), $D$ is a sex dummy (woman=1), Age and Age $^{2}$ measure the seniority effect and 'Share' is the percentage of women in the different occupations. $e$ is the error term.

The results are shown in the table below: 
Table 6: Results from the regression with $\ln (w)$ as the dependent variable. $t$-values in brackets.

\begin{tabular}{lll|}
\hline & HAY & BVT \\
\hline Constant & $9.067(65.631)$ & $8.801(187.053)$ \\
Points & $.0008(17.033)$ & $.0082(36.415)$ \\
Age & $.0174(2.848)$ & $.0212(9.510)$ \\
$(\text { Age })^{2}$ & $-.0001(-2.171)$ & $-.0002(-8.515)$ \\
Woman(=1) & $-.0433(-3.558)$ & $.0071(.776)$ \\
Share & $-.0012(-4.484)$ & $-.0005(-4.691)$ \\
$(\%$ women $)$ & & .77 \\
$\mathrm{R}^{2}$ adj & .75 &. \\
\hline
\end{tabular}

For both equations, the share of women in the occupations appears as a significant variable in determining the wage rate. This means that the general wage level (for both men and women) is lower in jobs dominated by women when the difficulty of the job (as measured by the job-evaluation points) is held constant. The size of the effect in the BVT-equation is half of that in the HAY-equation. Wages fall about 0.5 per cent for each 10 per cent increase in the share of women in the BVT-evaluation and by 1.2 per cent for the HAY case. This indicates a difference in the general wage rate of 5 per cent according to BVT and 12 per cent according to HAY between a totally male dominated and a totally female dominated occupation with the same productivity level.

As was the case with the individual values, when a job-evaluation is implemented it does not imply that all female dominated jobs will receive higher wages. This is illustrated in Figure 3, where wage changes (according to equation (1)) are calculated for 12 femaledominated and 12 male-dominated occupations. 
Figure 3: Estimated changes in wages for male- and female jobs due to job-evaluation results (BVT).

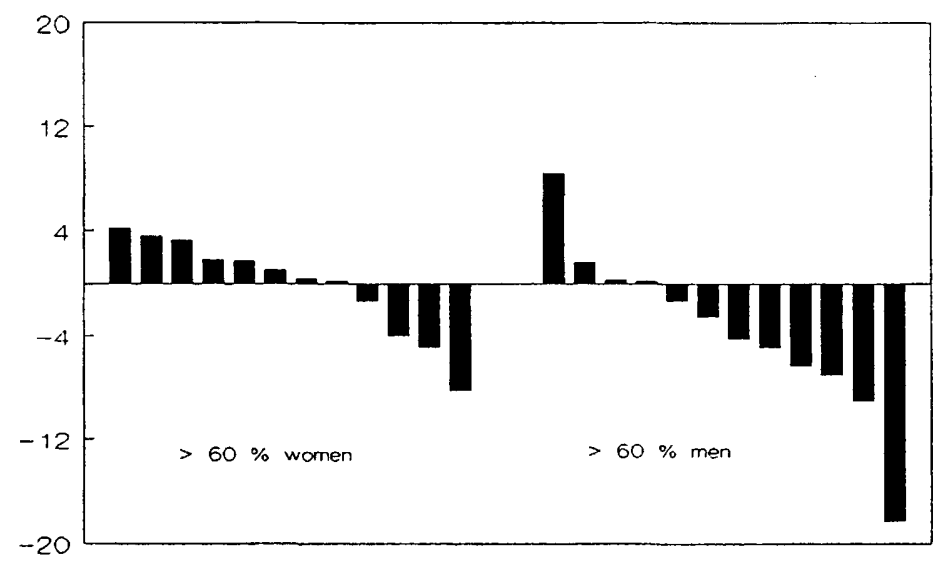

The figure shows that that there is no uniform pattern of wage changes with respect to sex-domination in an occupation. Female- as well as male-dominated jobs might be both over- and under-paid with regard to the average evaluation points. The figure illustrates, however, both that a decline in the general wage rate is more likely if it is a male dominated job (which of course is to be expected given the results in Table 5) and that the expected changes (both positive and negative) are much greater for occupations dominated by men.

Finally, it can be observed from Table 6 that, in the HAY-equation, both the share of women and the dummy for women are statistically significant at the $99 \%$ confidence level. In the BVT-equation, only the share is significant. The interpretation of the result from the HAY-equation is that wage discrimination has two aspects. First, women are not paid at the same rate as men, given the degree of difficulty or the level of demand of the specific job. Second, jobs dominated by women are regarded as less important or valuable and, therefore, receive a lower general wage rate than other comparable jobs.

\section{Conclusions}

There have been many objections to the increased use of systematic job-evaluation. Basically, the argument is that one should not interfere with the market forces, and that job-evaluation is only another distortion of the free market forces. Further, as a distortion, it can only lead to less efficiency in production.

The approach taken in this paper is the reverse: systematic job-evaluation is seen as a way to improve information on the true productivity of different jobs. Adjusting wages 
according to the results from a job-evaluation study is regarded as improving the functioning of the market and not as something that disturbes the market.

The core question of the paper is the influence of job-evaluation on women's wages. 18 More specifically, we ask whether wages set according to a job-evaluation study would increase or decrease womens wages. Two different evaluation studies were used to answer this question. The general result was that if job evaluation only set wages, then this would lead to an increase in women's wages and a decrease in men's wages. The result is, however, not uniform in the sense that all women, or all occupations dominated by women, would receive higher wages. Neither would all men or all male-dominated occupations experience lower wages. Looking at the individual data, we found that 50 out of one hundred women would have a wage increase, 30 a decrease and 20 would have an unchanged wage rate, if there was a strict implementation of the results from the job-evaluation carried out here.

The general result is, accordingly, that job-evaluation can improve women's wages. Nevertheless the question still remaining to be answered is whether or not job evaluation really is a better measurement of productivity than the market wage. Is it possible to correct the lower wages in the female dominated jobs without systematic evaluation? Today we are very much aware of the market's role in the wage setting process. However, since we are also aware of the existence of valuations, judgements, adjustments etc in the wage setting process systematic job evaluation will probably continue to be on the agenda for quite a while and at least until other methods are found for correcting unfair wages. to the results from the job evaluations. Various American studies have pointed to small negative effects on employment. One reason to this may be small substitution possibilities for the types of jobs often considered in the job evaluation process. (See e g Ehrenberg \& Smith (1991) and Killingworth (1990). 


\section{REFERENSER}

Aaron, H.J \& Lougy, C.M (1986) The Comparable Worth Controversy. The Brookings Institute, Washington D.C.

Acker, J (1989) Doing Comparable Worth. Gender, Class and Pay Equity. Temple University Press, Philadelphia.

Audie-Figueroa, A. (1983) Sex, power and wages: An economic study of comparable worth. (Diss.) University of Wisconsin, Madison.

Barth, E (1993) Pay Differentials and Bargaining Institutions. Five essays in wage determination with empirical evidence from Norway. (Diss.) Socialokonomisk institut, University of Oslo.

Blau, F \& Ferber, M (1992) The Economics of Women and Work.

Ehrenberg, R.G \& Smith, R.S (1987) Comparable-Worth Adjustments and Female Employment in the State and Local Sector. Journal of Labor Economics, vol 5, no 1.

Evans, S.M \& Nelson, B.J (1989) Wage Justice. Comparable Worth and the Paradox of Technocratic Reform. The University of Chicago Press.

Gunderson, M (1989) Male-Female Wage Differentials and the Policy Responses. Journal of Economic Literature 27 (March 1989).

Gunderson, M (1994) Comparable Worth and Gender Discrimination: An international perspective. International Labour Office, Geneva.

Killingworth, M. (1990) The Economics of Comparable Worth. Kalamazoo Michigan WE, Upjohn Institute for Employment Research.

Löfström, $\AA$ (1989) Wage Discrimination in the Swedish Labour Market. An Analysis of Wage Differentials between Women and Men. (Diss. in Swedish) Umeå Economic Studies 1989:196. University of Umeå.

Löfström, $\AA$ (1992) Comparable Worth - Prerequisite for Wage Justice Women-Men? (in Swedish). Ekonomisk Debatt No 3, 1992.

Palme, M.O \& Wright, R.E (1992) Gender discrimination and compensating differentials in Sweden. Applied Economics, 1992, 24, 751-759.

Perlman, R \& Pike, M (1994) Sex Discrimination in the Labour Market. The case of comparable worth. Manchester University Press. 
Polachek, S.W. \& Siebert, W.S (1993) The Economics of Earnings. Cambridge Universiy Press.

Sorensen, E (1990) The Crowding Hypothesis and Comparable Worth. Journal of Human Resources vol 25 no 1 winter 90.

Sorensen, E (1994) Comparable Worth. Is it a Worthy Policy?

Princeton University Press, Princeton, New Jersey.

Weiner, N \& Gunderson, M (1990) Pay Equity. Issues, Options and Experiences. Butterworth. 


\section{UMEÅ ECONOMIC STUDIES}

\section{(Studier i nationalekonomi)}

All the publications can be ordered from Department of Economics, University of Umeå, S-901 87 Umeå, Sweden.

Umeå Economic Studies was initiated in 1972. For a complete list, see Umeå Economic Studies No 325 and earlier.

326 Hultkrantz, Lars: Effektivitet i offentlig sektor - färdriktningar för reformarbetet, 1994.

327 Aronsson, Thomas and Wikström, Magnus: The Influence of a Nonlinear GrantIn-Aid on Local Public Expenditures in Sweden, 1994.

328 Aronsson, Thomas: A Simple Test for Weak Separability Between Male and Female Labour Supply, 1994.

329 Löfgren, Karl-Gustaf: The Spatial Monopsony and Monopoly under Uncertainty: Properties of the Profit Functions, 1994.

330 Friesz, Terry L., Westin, Lars and Suo, Zhong-Gui: A Spatial Computable General Equilibrium Model, 1994.

331 Brännlund, Runar and Löfgren, Karl-Gustaf: Emission Standards and Stochastic Waste Load, 1994.

332 Brännlund, Runar, Färe, Rolf and Grosskopf, Shawna: The Cost of Environmental Regulation: A Programming Approach, 1994.

333 Aronsson, Thomas and Brännäs, Kurt: Household Work Travel Time, 1994.

334 Aronsson, Thomas and Brännäs, Kurt: Labour Supply in an Empirical Model of Locational Choice, 1994.

335 Brännäs, Kurt: Estimation and Testing in Integer-Valued AR(1) Models, 1994.

336 Lundberg, Johan: Satelliträkenskaper för besöksnäringen i Sverige 1991, 1994.

337 Nordström, Anna: Arbetsmarknadspolitiska åtgärder för arbetshandikappade. En contingent valuation-undersökning, 1994.

338 Bergman, Mats: The restricted profit function and the application of the generalised Leontief and the translog functional forms, 1994.

339 Isaksson, Torbjörn: Stordriftsfördelar, transportkostnader och regional obalans. En studie av Krugmans lokaliseringsmodell, 1994. 
340 Roson, Roberto: Transport Networks and the Spatial Economy. A General Equilibrium Analysis, 1994. PhD thesis.

341 Li, Chuan-Zhong: Welfare Evaluations in Contingent Valuation. An Econometric Analysis, 1994. PhD thesis.

342 Østbye, Stein: Regional Subsidies on Labour and Capital under Wage Bargaining, 1994.

$343 \varnothing$ stbye, Stein: The Impact of Labour and Capital Subsidies on Employment, 1994.

344 Østbye, Stein: Regional Labour and Capital Subsidies. Theory and Evidence of the Impact on Employment under Wage Bargaining, 1994. PhLic thesis.

345 Johansson, Per-Olov and Löfgren, Karl-Gustaf: On the Interpretation of 'Green' NNP Measures as Cost-Benefit Rules, 1994.

346 Tyteca, Daniel: On the Measurement of Environmental Performance in Firms Literature Review and Productive Efficiency Approach, 1994.

347 Bergman, Mats: Producentkooperativ och marknadsmakt. Den nya konkurrenslagen, effektivitet i den jordbrukskooperativa industrin och de svenska livsmedelspriserna, 1994.

348 Zhang, Wei-Bin: A Structural Two-Group Growth Model with Capital and Knowledge, 1994.

349 Zhang, Wei-Bin: Family Preference and Sexual Division of Labor. Economic Growth with Capital and Knowledge, 1994.

350 Zhang, Wei-Bin: Wealth Distribution and Unemployment. Endogenous Capital and Knowledge in a Two-Group Growth Model, 1994.

351 Aronsson, Thomas and Palme, Mårten: A Decade of Tax and Benefit Reforms in Sweden - Effects on Labour Supply, Welfare and Inequality, 1994.

352 Johansson, Per-Olov and Löfgren, Karl-Gustaf: On the Value and Optimal Protection of a Patent, 1994.

353 Aronsson, Thomas and Wikström, Magnus: Regional Responses in Local Expenditures to Intergovernmental Grant Reform in Sweden. An Experiment Based on Repeated Cross-Section Data, 1994.

354 Aronsson, Thomas and Karlsson, Niklas: The Influence of Quantity Constraints on Women's Hours of Work in the Household Labour Supply Model, 1994.

355 Norén, Ronny: Omvandlingsperspektiv och konkurrensprofil i förändring. En studie av svensk industriell omvandling 1972 - 1990, 1994. 
356 Puu, Tönu: The Chaotic Duopolists, 1994.

357 Puu, Tönu: The Chaotic Monopolist, 1994.

358 Norén, Ronny: Ekonomisk tillväxt i ett strukturellt omvandlingsperspektiv, 1994.

359 Färe, Rolf, Grosskopf, Shawna and Tyteca, Daniel: An activity analysis model of the environmental performance of firms - Application to fossil fuel-fired electric utilities, 1994.

360 Hultkrantz, Lars and Olsson, Christina: Chernobyl Effects on Domestic and Inbound Tourism in Sweden - A Time Series Analysis, 1994.

361 Hultkrantz, Lars: On Determinants of Swedish Recreational Domestic and Outbound Travel, 1989-1993, 1994.

362 Löfgren, Karl-Gustaf: Knut Wicksell on the Optimal Rotation Problem in Forestry, 1994.

363 Johansson, Per: Tests for Serial Correlation and Overdispersion in a Count Data Regression Model, 1994.

364 Brännäs, Kurt and Eriksson, Maria: Enrolment in Labour Market Training Programs, 1994.

365 Weichenrieder, Alfons J.: Transfer Pricing, Double Taxation, and the Cost of Capital, 1994.

366 Aronsson, Thomas and Löfgren, Karl-Gustaf: Social Accounting and Welfare Measurement in a Growth Model with Human Capital, 1994.

367 Zhang, Wei-Bin: Growth with Renewable Resources, 1995.

368 Zhang, Wei-Bin: Economic Dynamics with Livestock, 1995.

369 Zhang, Wei-Bin: An Agricultural Equilibrium Model with Two Groups, 1995.

370 Aronsson, Thomas and Wikström, Magnus: Local Public Expenditures in Sweden.

A Model where the Median Voter is not Necessarily Decisive, 1995.

371 Aronsson, Thomas, Johansson, Per-Olov and Löfgren, Karl-Gustaf: Investment Decisions, Future Consumption and Sustainability under Optimal Growth, 1995.

372 Hultkrantz, Lars: Dynamic Price Response of Inbound Tourism Guest-Nights in Sweden, 1995.

373 Brännäs, Kurt and Johansson, Per: Panel Data Regression for Counts, 1995. 
374 Berglund, Elisabet and Brännäs, Kurt: Entry and Exit of Plants: A Study Based on Swedish Panel Count Data, 1995.

375 Brännäs, Kurt and Karlsson, Niklas: Endogeneity Testing in Micro-Econometric Models, 1995.

376 Aronsson, Thomas, Johansson, Per-Olov and Löfgren, Karl-Gustaf: On the Proper Treatment of Defensive Expenditures in 'Green' NNP Measures, 1995.

377 Westerlund, Olle: Employment Opportunities, Wages and Interregional Migration in Sweden 1970-1989, 1995.

378 Axelsson, Roger and Westerlund, Olle: A Panel Study of Migration, Household Real Earnings and Self-Selection, 1995.

379 Westerlund, Olle: Economic Influences on Migration in Sweden, 1995. PhD thesis.

380 Aronsson, Thomas, Brännlund, Runar and Wikström Magnus: Wage Determination under Nonlinear Taxes - Estimation and an Application to Panel Data, 1995.

381 Brännäs, Kurt: Explanatory Variables in the AR(1) Count Data Model, 1995.

382 Norén, Ronny: Industrial Transformation in the Open Economy - A Multisectoral View, 1995.

383 Brännäs, Kurt and Ohlsson, Henry: Asymmetric Cycles and Temporal Aggregation, 1995.

384 Brännlund, Runar, Chung, Yangho, Färe, Rolf and Grosskopf, Shawna: Emissions Trading and Profitability: The Swedish Pulp and Paper Industry, 1995.

385 Nordström, Jonas: Tourism Satellite Account for Sweden 1992-1993, 1995.

386 Brännlund, Runar, Löfgren, Karl-Gustaf and Sjöstedt, Sara: Forecasting Prices of Paper Products: Focusing on the Relation Between Autocorrelation Structure and Economic Theory, 1995.

387 Østbye, Stein: Real Options, Wage Bargaining, Regional Subsidies and Employment, 1995.

388 Østbye, Stein: A Real Options Approach to Investment in Factor Demand Models, 1995.

389 Bergman, Mats A.: Price Competition under Capacity Constraint with Endogenous Timing of Entry, 1995. 
390 Vredin, Maria: Values of the African Elephant in Relation to Conservation and Exploitation, 1995.

391 Bergman, Mats A.: Antitrust, Marketing Cooperatives and Market Power, 1995.

392 Brännäs, Kurt and Karlsson, Niklas: Estimating the Perceived Tax Scale within a Labor Supply Model, 1995.

393 Sjögren, Tomas and Brännäs, Kurt: Recreation Travel Time Conditional on Labour Supply, Work Travel Time and Income, 1995

394 Löfgren, Karl-Gustaf, Nordström, Anna and Nyman, Pär: Willingness to Pay for Work Programs for Disabled Workers, 1995

395 Backlund, Kenneth, Kriström, Bengt, Löfgren, Karl-Gustaf and Polbring, Eva: Global Warming and Dynamic Cost-Benefit Analysis Under Uncertainty: An Economic Analysis of Forest Carbon Sequestration, 1995

396 Mortazavi, Reza: Three Papers on the Economics of Recreation, Tourism and Property Rights, 1995. PhLic thesis

397 Østbye, Stein: Regional Labour and Capital Subsidies, 1995. PhD thesis

398 Bask, Mikael: Dimensions and Lyapunov Exponents from Exchange Rate Series, 1995

399 Aronsson, Thomas, Backlund, Kenneth and Löfgren, Karl-Gustaf: Nuclear Power, Externalities and Non-Standard Pigouvian Taxes: A Dynamic Analysis under Uncertainty, 1996

400 Johansson, Per and Brännäs, Kurt: A Household Model for Work Absence, 1996

401 Löfström, Åsa: Arbetsvärdering i akademin. Hur lönestrukturen kan påverkas i ett företag som arbetsvärderat, 1996

402 Zhang, Wei-Bin: Knowledge, Infrastructures and Economic Structure, 1996

403 Zhang, Wei-Bin: Economic Growth, Housing and Residential Location, 1996

404 Zhang, Wei-Bin: Taste Change, Economic Growth and Structural Transformation, 1996

405 Brännäs, Kurt, de Gooijer, Jan and Teräsvirta, Timo: Testing Linearity against Nonlinear Moving Average Models, 1996

406 Bergman, Mats A: Estimating Investment Adjustment Costs and Capital Depreciation Rates from the Production Function, 1996

407 Löfström, Åsa: Variation in Female Activity and Employment Patterns: The case of Sweden, 1996 
408 Zhang, Wei-Bin: Knowledge and value - Economic Structures with Time and Space, 1996.

409 Hussain-Shahid, Imdad: Benefits of Transport Infrastructure Investments: A Spatial Computable General Equilibrium Approach, 1996. PhD thesis.

410 Eriksson, Maria: Selektion till arbetsmarknadsutbildning, 1996. PhLic thesis.

411 Karlsson, Niklas: Testing for Normality in Censored Regressions, 1996

412 Karlsson, Niklas: Testing for Exponential and Weibull Distributions in Censored Duration Models, 1996

413 Karlsson, Niklas: Testing and Estimation in Labour Supply and Duration Models, 1996. $\mathrm{PhD}$ thesis.

414 Weitzman, Martin L. and Löfgren, Karl-Gustaf: On the Welfare Significance of Green Accounting as Taught by Parable, 1996

415 Aronsson, Thomas and Löfgren, Karl-Gustaf: An Almost Practical Step towards "Green" Accounting?, 1996

416 Löfström, Åsa: Can Job Evaluation Improve Women's Wages?, 1996 